\title{
Geology and Petrographic Study of the Granitic Rocks of Kaltungo Inlier, Northeastern Nigeria
}

\author{
A. S. Sa' ${ }^{1}{ }^{1}$ and S. Baba ${ }^{2}$ \\ (Department of Geology, University of Maiduguri, Borno State. Nigeria)
}

\begin{abstract}
Geological mapping of Kaltungo inlier was carried out, and a geological map of the area was produced. The area is dominantly underlain by porphyritic granites, coarse biotite granites and medium grained granites. Bima sandstone and some volcanic rocks mainly basalts intruding the sandstone have also been mapped. However, this work is essentially centralised on the granitic rocks. The samples of the granitic rocks were analysed in the field using hand lens and in the laboratory using a polarizing microscope. The essential minerals identified are quartz, feldspars (albite, orthoclase, microcline and andesine), biotite, hornblende, muscovite and the accessory minerals are sphene, zircon, iron oxide, sericite, limonite, and myrmekite. Though the rocks are all granites, they exhibit some variations in their colour, texture and to some extent their mineral compositions.
\end{abstract}

Keywords: Geologic mapping, Petrographic study, Granitic rocks, Kaltungo Inlier, Polarizing

microscope.

\section{Introduction}

Previous study of the area shows that the area is underlain by a sequence of rock units; Basement rocks, Bima sandstone, Yolde Formation, Fika Shale, Pindiga Shale and Basaltic rocks. The rock types of the Kaltungo area which is as a result of sedimentary, volcanic and plutonic activities include Kaltungo/Tangale porphyritic granites of the Older Granite Suites, the Bima Sandstone, Yolde Formation, Fika Shale, Pindiga Shale and Basalt Flows. (Benkhelil and Robineau, 1983)[2]. The area under study falls within the Upper Benue Trough and lies between latitudes $9^{\circ} 45^{\prime} \mathrm{N}$ and $9^{\circ} 50^{\prime} \mathrm{N}$ and longitudes $11^{\circ} 15^{\prime} \mathrm{E}$ and $11^{\circ} 20^{\prime} \mathrm{E}$ on Kaltungo sheet 157 $(1: 50,000)$ and occupies the southern part of Gombe State, Northeastern Nigeria.

Granites of the crystalline basement occur in the foreground. The phonolite plug forming the Tangale peak pierces gently the dipping Bima Sandstone. Basalt plugs form the hills to the right of the peak. (Carter et. $a l, 1963)[3]$ The granites near the Pieta, Walama, and Burashika contain large bodies of migmatite. Migmatite forms the greater part of Gombe hill. In the Kaltungo inlier, small rafts of coarsely banded migmatite occur in the equigranular granites in the hills near Billiri (Carter et. al, 1963)[3] Biotite-granite with very small amounts of muscovite occurs in strips along the northern, western and southern margins of the Kaltungo inlier. In the south, biotite-granite attains its maximum development in the great ranges of hills which extend westwards for nearly 50miles from Bajama to Minda. In this area, the rocks are usually very coarse-grained and include considerable developments of metacrystic varieties. (Carter et. al, 1963)[3]. the northern end of Gombe hill, the eastern half of Liji hill and part of Zambuk inlier are formed by biotite-muscovite-granite. In the Kaltungo inlier, the biotite-granites carry a little primary muscovite, which however, is not discernible in the hand specimen. (Carter et. al, 1963)[3] The Kaltungo coarse porphyritic granite occupies the greater part of the Kaltungo inlier. It forms most of the hills and peaks between Kaltungo and Billiri and underlies the severally eroded 'badlands' in the central and north-eastern part of the inlier. The coarse porphyritic granites are poor in minor acid segregations such as pegmatite, aplite and quartz veins. Pegmatite takes the form of irregular, quartz-feldspar bodies a few feet in length and a few inches wide. Occasionally pegmatite with subordinate magnetite forms concentration along the granite contacts; examples of these are present in the Kaltungo inlier and at Zobe hill. (Carter et. al, 1963)[3].

This present work is aimed at producing a geologic map of the study area, also to have the knowledge of rock identification and to know the petrographic properties of some minerals that could not be ascertained and discernible in the field using naked eyes or a hand lens.

\section{Geology}

The basement complex of Nigeria underlies nearly half of the entire country and extends to the west into the Dahomey (Benin) and in the east into the Cameroons. In the remaining 50\% of the country, cretaceous and younger sediments cover the basement complex. In the central area, the basement complexes have been intruded by high level granites and porphyries of Jurassic age as ring complexes. Tertiary volcanic rocks, mostly 
basalt cover small areas of the basement complex mostly in the northeast. The oldest known rocks in the country are Precambrian in age.

\section{Geologic Review of the Basement Complex rocks of Nigeria}

The Nigerian basement complex is made up of three lithological units; the Migmatite-Gneiss-Quartzite complex, the Metasediments or Schist Belts and Older Granite Suite.

Migmatite-Gneiss-Quartzite complex: this consists of migmatite gneisses, banded gneiss, augen gneiss, some high grade schist and amphibolites as well as quartzites and marbles. This unit is believed to be the oldest part of the Nigerian basement on which other rocks are laid and have been emplaced.

The Metasediments or Schist Belts: these are groups of rocks that occupy the narrow North-South troughs which are more abundant in the western part of the country, west of longitude $8^{0}$. Schist belts are believed to have been deposited on the migmatite gneiss complex either during the Kibaran or Pan African Orogeny or both. Schist belts are generally of low-medium grade metamorphism and composed mainly of fine grained clastic sediments which include phyllites, pelites, mica schist and coarse clastic rocks which include metaconglomerates and metasandstones. Volcanic rocks and volcanoclastics form a relatively small percent of the rocks. The belts are usually separated from each other by migmatite gneiss complex as well as older granitic rocks.

The Older Granites: the term "Older Granites" was first used by Falconer (1911)[4] as a descriptive label to encompass a Precambrian suite of plutonic rocks which include granites, coarse porphyritic / porphyritic granites, Adamallites, granodiorites, quartz diorites, tonolites, charnokites and gabbros. They occur as prominent batholitic masses in many parts of the basement complex. The term also differentiates the rocks from the high level intrusive Jurassic granites of the Jos plateau (the Younger Granites). The Older Granites are believed to have intruded into both migmatite-gneiss-quartzite complex and the rocks of the schist belts.

The Nigerian basement can be divided into four regions namely; Northwest, Southwest, North central-Northeast and Southeast. Each of these regions has its own characteristics lithologies and differs in modes of formation.

\section{The Basement Complex of Northeastern Nigeria}

The basement complex of Northeastern Nigeria is known to be composed of migmatite-gneiss-quartzite complex which have been intruded by extensive bodies of Pan African granites. Metasedimentary or schist belts are missing or conspicuously absent in this region. Only relics of the metasediments are found as xenoliths and small pendants in the granitic rocks (Carter et al, 1963)[3]

The oldest rocks comprise of the remnants of an ancient metasedimentary series now almost entirely transported into anatectic migmatites and granites through the process of granitization and migmatization. Other rock types include schist and quartzites. Relics of the younger metasediments found as xenoliths and small pendants include quartzites, marbles, calc-silicate rocks, quartz-feldspathic and quartz-mica schist.

The Older Granites exposed in the northeastern region occur in the form of batholiths, bosses and stocks as exemplified by the granites in the northern part of Mandara Hills and around Bauchi and Jalingo areas.

Islam and Baba (1988)[5] have differentiated the Older Granites of the northern part of the Mandara Hill into medium and coarse grained granites, coarse porphyritic granites, fine grained granites, pegmatites and aplites including quartz veins. Pegmatites and aplites occur all over the region cross-cutting other rock types.

The northeastern basement complex is characterised by the presence of charnokites rocks including Bauchites. Charnokites are black or dark greenish grey or dark blue rocks composed of quartz, alkali feldspars, plagioclase, orthopyroxene (hypersthenes), clinopyroxene, hornblende, biotite and accessories apatite and zircon. Bauchites on the other hand is a deep green or blue grey coloured rock. It is typically coarse grained with feldspars in a matrix of ferromagnesian (fayalite and pyroxenes), quartz with accessory apatite, zircon and magnetite. Fayalite is the distinguishing mineral between Bauchites and Charnokites.

Kaltungo inlier is a Precambrian rock which is surrounded by sedimentary rocks of Cretaceous. The coexistence of their contact is of two possibilities:

i. The hill was as high that sedimentation was not able to cover its top.

ii. The hill was covered by sedimentation that gradually exposed over geologic time.

\section{Bima Sandstone}

The Bima Sandstone directly overlies the crystalline basement unconformably varying in thickness from $100 \mathrm{~m}$ to over $300 \mathrm{~m}$. This wide variation in thickness may be due to the irregular relief of the crystalline floor or variable degree of deposition. The Bima Sandstone probably results from the weathering of the granite on the Jos plateau. On Lamurde anticline, it is divided into upper, middle and lower. The type locality is at Bima hill $40 \mathrm{~km}$ east of Gombe where over $450 \mathrm{~m}$ of coarse feldspathic grits with subsidiary sandstones and ironstones are exposed. The mineral grain of Bima Sandstones is believed to be derived from granitic terrain. Bima sandstone is massively bedded, highly consolidated and almost recrystallized. The lower beds of this formation are composed of about $400 \mathrm{~m}$ of sandstone and argillaceous rocks. The middle is composed of about $800 \mathrm{~m}$ of 
coarse grained sandstone with clay and shale, whilst the upper division is about $1,700 \mathrm{~m}$ of coarse grained sandstone. The beds are cross bedded and show a large range of sedimentary structures which include flow structure and ripple marks. (Carter et al., 1963)[3]

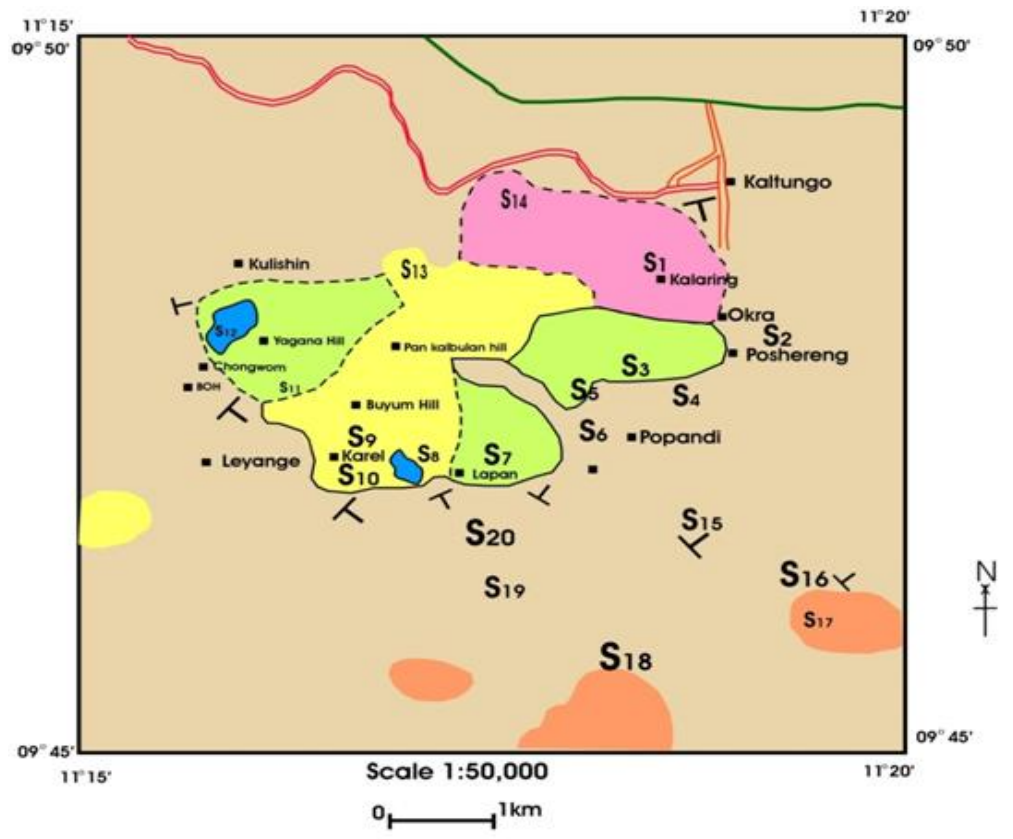

LEGEND:
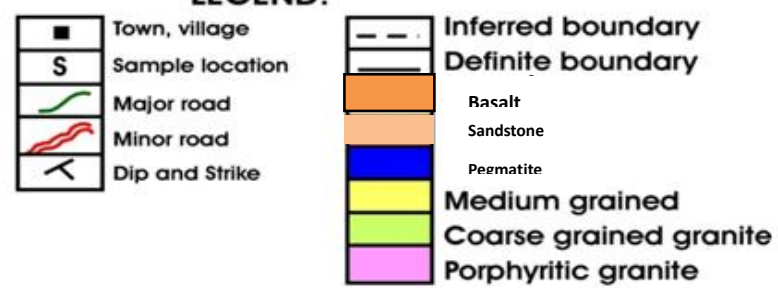

Fig. 1: Geological Map of the Study Area

\section{Field relation}

Three lithologies have been encountered; these are the Basement Complex rock which occurs as inlier mainly the granites, the Cretaceous sedimentary formations mainly the Bima Sandstone and the Tertiary/Quarternary basalts. However, this work is basically on the granitic rocks. Below is a hand specimen description:

\section{Porphyritic Granite (samples 1, 4 and 14)}

The rocks are pinkish dark to greenish in colour with porphyritic texture and essentially composed of major minerals in order of abundance of feldspar, quartz, biotite and hornblende. The phenocrysts are mainly feldspathic and range in size between $2 \mathrm{~cm} \times 1 \mathrm{~cm}$ to $3.5 \mathrm{~cm} 2 \mathrm{~cm}$ (N $09^{\circ} 48^{\prime} 32^{\prime \prime}$, E $\left.011^{\circ} 18^{\prime} 20^{\prime \prime}\right)$.
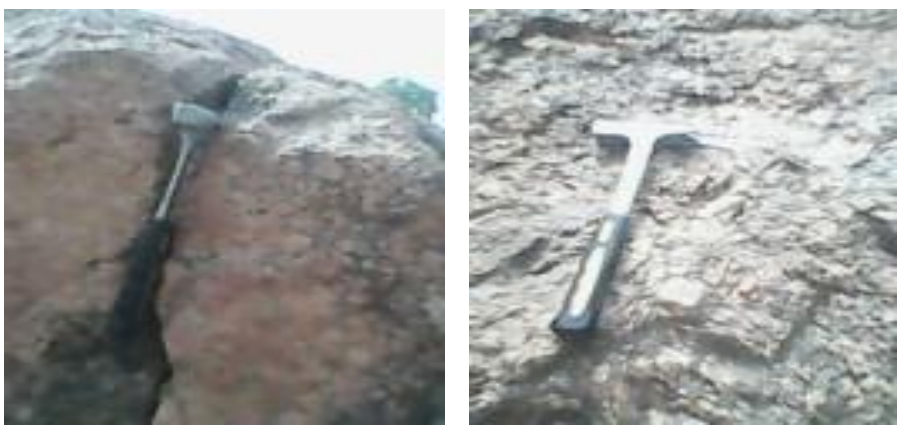

Fig. 2: Porphyritic Granites 


\section{Coarse Biotite Granite (sample 2, 5 and 7)}

The rocks are pinkish dark to gray with a very coarse grained texture and composed of major minerals of feldspar, biotite and quartz. (N09 $47^{\prime} 45^{\prime \prime}$, E $011^{0} 18$ '37'')

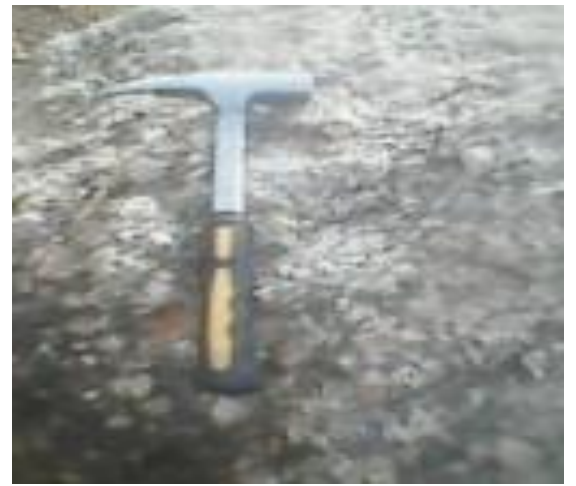

Fig. 3: Coarse Biotite Granite

\section{Medium Grained Granite (sample 9 and 10)}

The rocks are pinkish dark to gray with a medium grained texture and essentially composed of feldspar, biotite, quartz and hornblende. The hornblende is only suspected to be in sample 10 (N $09^{0} 47^{\prime} 10^{\prime}$ ', E $011^{0} 16^{\prime} 50^{\prime}$ ').

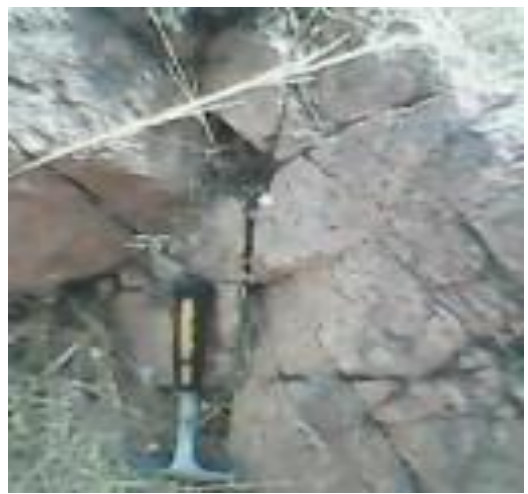

Fig. 4: Medium Grained Granite showing some Fractures

\section{Materials and Methodology}

The map of the study area was cut from a topographic map of a scale 1:50,000 and was not blown so that the scale remains the same. The mapping exercise was carried out on the field, a grid type of traversing was adopted in order to pace and cover the entire map. Rock samples were chipped and collected at regular intervals and at points of interest where there is change in lithology in order to mark and establish boundary between different rock types or units. Collected samples are labelled based on their locations as sample one (S1) for instance, and kept in a sample bag. However, prior to that certain observations were made such as colour, mineral composition, texture, measurements of thickness of structures, dip and strike, naming of the rock type and so on were all recorded in the field notebook.

The equipment/instruments needed by a geologist to carry out a successful fieldwork effectively are relatively few and are in fact common but their types can vary depending on the rock types to be mapped. Field equipment used include; Base Map, map case, Compass and Clinometers, Geographic Positioning System (GPS), Measuring Tape, Hammers and Chisels, Hand lens, Diluted Acid, Sample Sac, Masking Tape, Camera, Field note book, Pen, Pencil and erasers. (Baba, 2009)[1]. The samples were then taken to the laboratory and subjected to a petrographic analysis. The collected samples were thin sectioned with each sample prepared on two slides.

\section{Thin Section Preparation}

Abrasive Powders used in this work are therefore grade 120 and grade 600 respectively, and the required thickness as usual was determined by the reference minerals, that is colour indexes of quartz and feldspar which is grey to white. 
Final Mount is done when the glass is allowed to dry and the excess araldite is being removed using a razor blade, a drop of Canada balsam is applied on the slide and the cover is then placed on top of it and pressed gently to remove any air bubbles as well as excess Canada balsam between the slides and the cover slip. Allow it to dry on a hot plate then remove the excess Canada balsam on the glass slide and then wash the slide with detergent and finally allow it to dry. (Rowland, 1953)[6]

\section{Petrographic Study}

The eight samples collected were thin sectioned, with each sample on two slides and were analysed and studied with a polarising microscope under both plane polarised light (PPL) and cross polarised light (XPL). The petrographic study revealed that:

Quartz appears to be colourless under plane polarized light, pleochroism and cleavage is absent, however, some fractures are apparent with an anhedral form and low relief. Conversely, it has weak birefringence under crossed polarised light; interference colour is gray to white of first order with parallel extinction and no twinning. Orthoclase is apparently colourless under plane polarized light, non pleochroic with cleavage perfect in two directions, anhedral form and low relief. On the other hand, it has weak birefringence under crossed polarised light, interference colour of gray to white of first order with parallel extinction and Carlsbad twinning.

Microcline is colourless under plane polarised light with perfect cleavage in two directions, anhedral form and low relief. Under crossed polarised light however, it appears to have weak birefringence, interference colour of gray to white of first order with parallel extinction and cross-hatch twinning.

Andesine is colourless and non pleochroic with perfect cleavage in two directions, anhedral form and low relief under plane polarised light. When observed under crossed polarised light, it has weak birefringence, interference colour of gray to white of first order with an oblique extinction at an angle of $24^{0}$ in slide $1 \mathrm{a}$ and $21^{0}$ in slide $1 \mathrm{~b}$ and an albite twinning. Plagioclase is colourless, non pleochroic with cleavage perfect in two directions, anhedral form and low relief under plane polarised light. It has weak birefringence, interference colour of gray to white of first order, with an oblique extinction at an angle of $16^{\circ}$ in slide 5 a and polysynthetic twinning though it was absent in slide $5 b$.

Biotite is observed to be brownish under plane polarised light with strong pleochroism, cleavage perfect in two directions, anhedral form and a high relief. However, it has strong birefringence under crossed polarised light, interference colour virtually greenish brown with parallel extinction and no twinning. Hornblende is light green under plane polarised light with strong pleochroism and perfect cleavage in two directions, anhedral form and very high relief. It has strong birefringence under crossed polarised light, interference colour of dark green with symmetrical extinction and polysynthetic twinning.

Muscovite appears colourless to pale yellow, non pleochroic with poor cleavage in one direction, moderate form and relief under plane polarised light. Birefringence is also moderate however, under crossed polarised light, interference colour between reddish to purple (multicolour) with parallel extinction and twinning absent. It was only observed in slide $5 \mathrm{~b}$.

Iron oxide looks blackish as observed under both plane and crossed polarised light (opaque), with absent pleochroism and cleavage, anhedral form and high relief. It has no birefringence, extinction and twinning is absent Sphene is apparently pale yellow to green in colour with no pleochroism and cleavage under plane polarised light, anhedral form and high relief. However, it tends to have a strong birefringence, interference colour of green arcane with symmetrical extinction and polysynthetic twinning under crossed polarised light. It was only observed in slide $2 \mathrm{a}$.

Zircon is greenish under plane polarised light with pleochroism and cleavage absent, prismatic form and moderate to high relief. It has strong birefringence, interference colour of upper second order, parallel extinction and twinning absent. Sericite appears colourless to pale yellow under plane polarised light, non pleochroic with a very poor cleavage in one direction, anhedral form and low to moderate relief. Conversely, it has moderate to high birefringence, interference colour between reddish to purple under crossed polarised light with parallel extinction and twinning is absent.

Myrmekite is colourless under plane polarised light, with pleochroism absent, cleavage perfect in two directions, anhedral form and low relief. It has weak birefringence, interference colour of gray to white of first order as seen under crossed polarised light, with parallel extinction and twinning absent. Limonite, just like an iron oxide, it is also an opaque mineral only that it has brown colouration under plane polarised light and dark brown under crossed polarised light. 


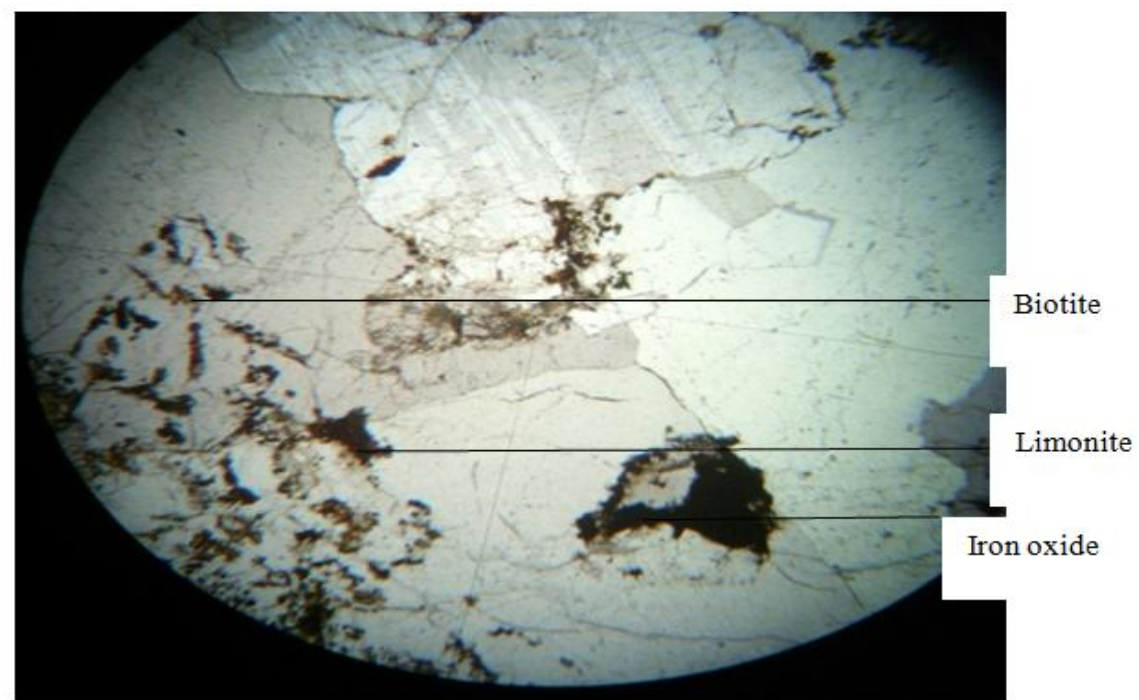

a. Minerals Observed Under Plane Polarized Light (Magnification x100)

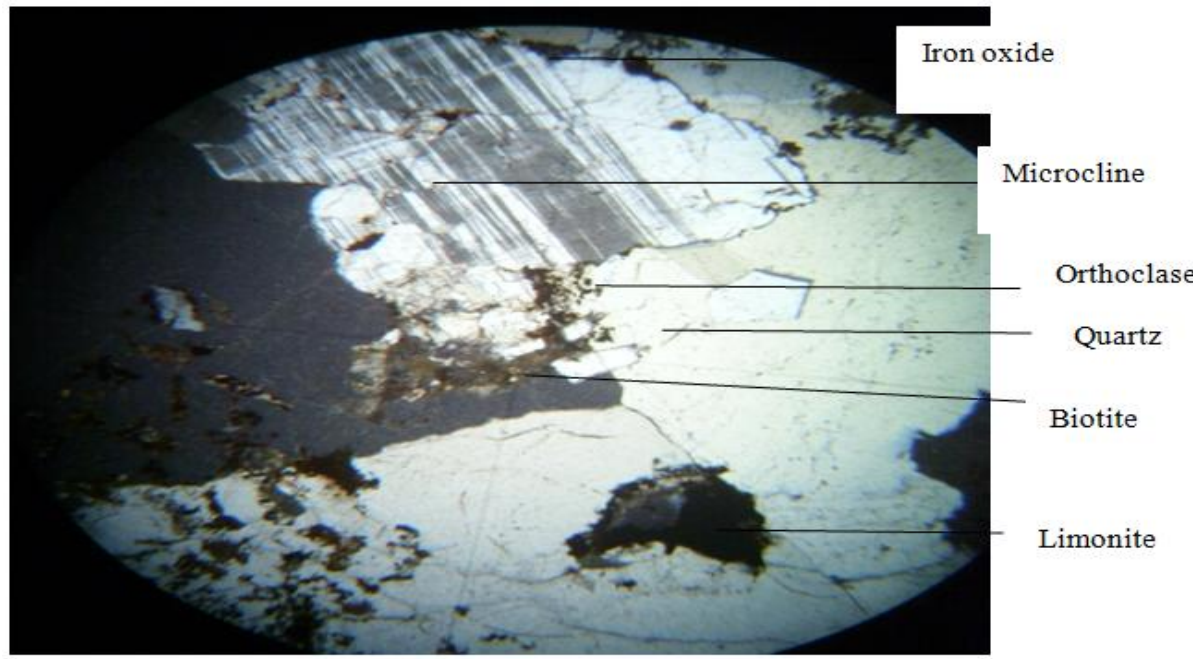

b. Minerals Observed Under Cross Polarized Light (Magnification x100)

Fig. 5: Microphotographs of Porphyritic Granite (Sample 1, Slide 1b)

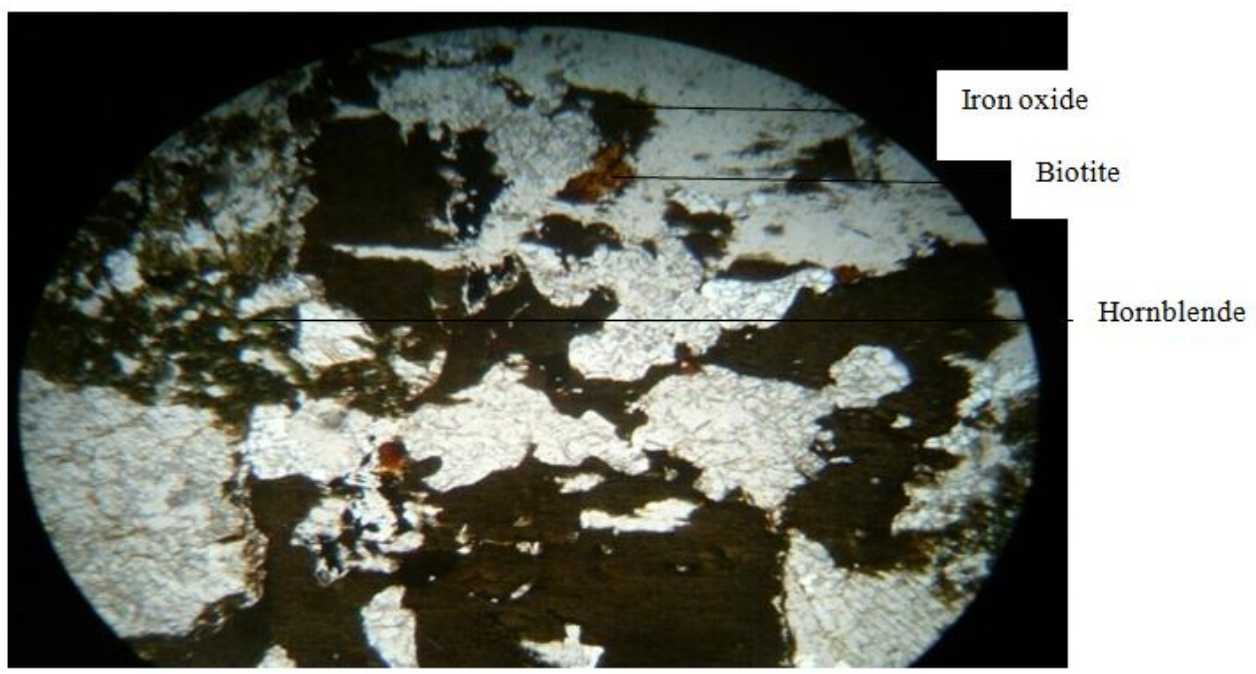

a. Minerals Observed Under Plane Polarized Light (Magnification x100) 


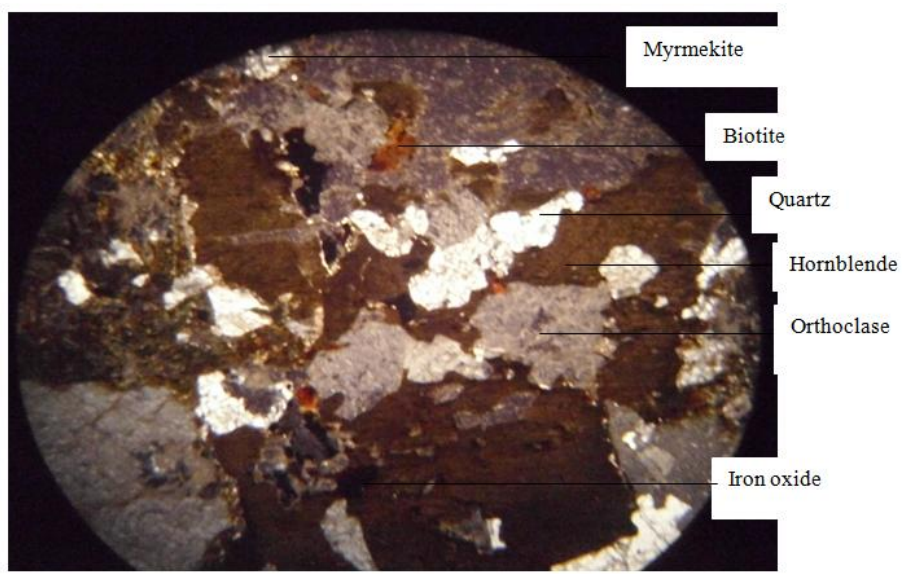

b. Minerals Observed Under Cross Polarized Light (Magnification x100) Fig. 6: Microphotographs of Coarse Grained Granite (Sample 7, Slide 7b)

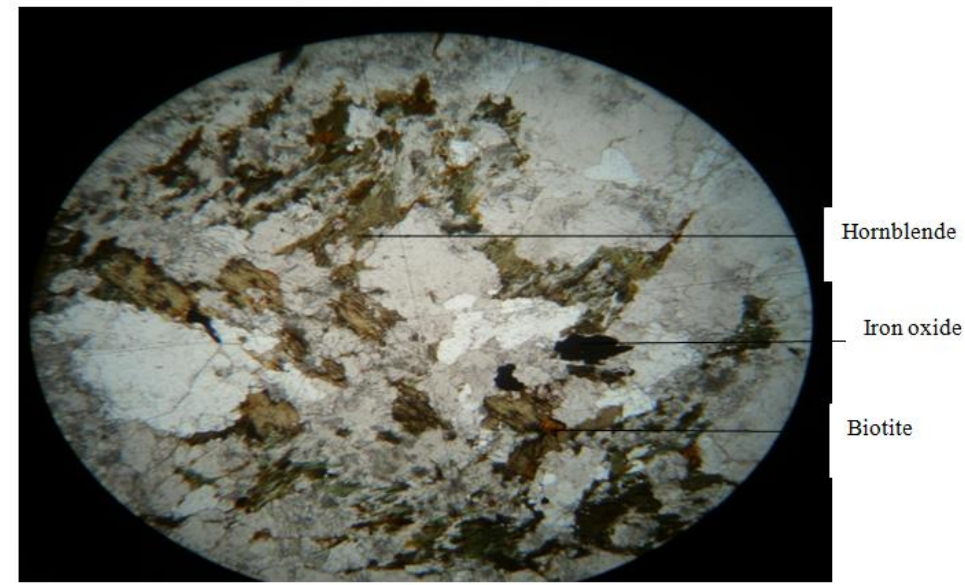

a. Minerals Observed Under Plane Polarized Light (Magnification x100)

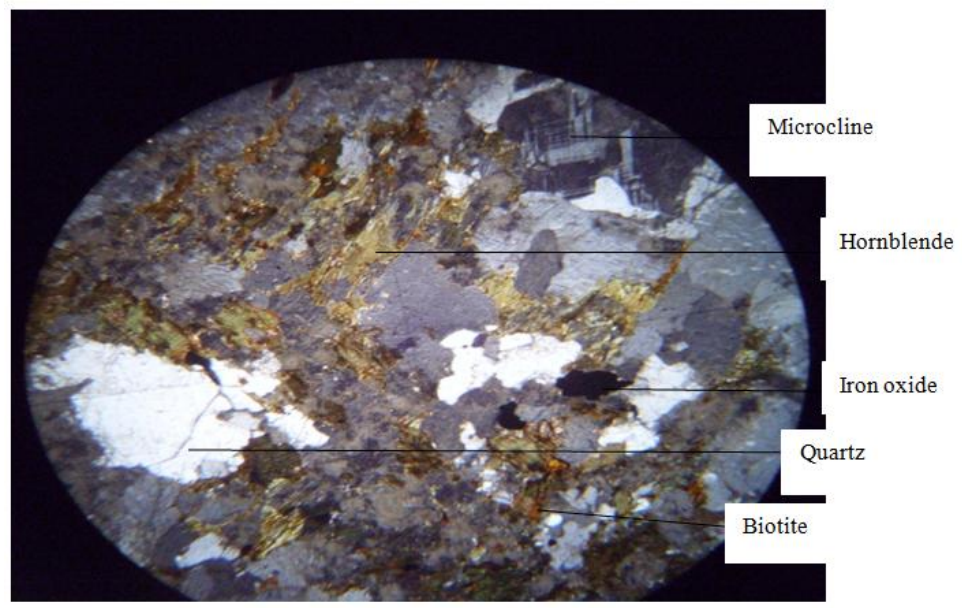

b. Minerals Observed Under Cross Polarized Light (Magnification x100)

Fig. 7: Microphotographs of Medium Grained Granite (Sample 9, Slide 9b)

\section{Discussion}

A geologic map of the study area was produced on a scale of 1:50,000. Though the rocks in the study area were identified to be granites, they exhibit some variations in their lithology. The granites consist of essentially quartz, albite, orthoclase, microcline andesine, biotite, hornblende, muscovite and accessory sphene, zircon, iron oxide, sericite, limonite, and myrmekite. The variation in their texture is basically as a consequence of the rate of cooling magma that formed the rocks. Some of the rocks have their mineral crystals well developed as a result of the fact that the magma had ample time to crystallise slowly beneath the earth surface 
where the temperature is favourable for each individual mineral crystal to grow. This is demonstrated in coarse grained granites (samples 2, 5 and 7). On the other hand, medium grained granites (sample 9 and 10) were more of rapid cooling magma and hence did not allow the individual mineral crystals to grow into larger crystals, thus given them medium textures in comparison with coarse grained granites. Porphyritic granites (Samples 1, 4, and 14) show characteristics of both slow and rapid rates of cooling magma. This is because it contains large or giant crystals of minerals (phenocrysts) due to slow cooling but then, it was subjected to a more rapid cooling as the magma eventually moves to the surface to form a finer grained groundmass in which the phenocrysts are embedded (porphyritic texture). The porphyries are mainly the pinkish feldspars as observed in the field, this happened because the feldspars are higher temperature minerals and they crystallized first. Medium grained granite (Sample 9 and 10) shows a change in texture observed in the field from top to bottom were subjected to a slower cooling relative to those at the top which were exposed to a rapid cooling. However, there are some scores of intrusions such as rhyolites and pegmatites that are not mappable encountered within the study area. Pegmatites may not necessarily form from a magmatic process but they always have affiliations to igneous bodies. Pegmatite vein (sample 8 and 12) is believed to have formed from the crystallization of the residual liquid of the end phase of magmatic crystallization which flow into fractures within the pre-existing rocks and crystallised. The residual liquid of the end phase of magmatic crystallization is acidic and rich in silica $\left(\mathrm{SiO}_{2}\right)$ which elaborates why the percentage of quartz is greater in composition to the other minerals present. In some parts of the pegmatite however, the feldspars are observed to be absent and quartz seems to be the only mineral present because of its resistance to both physical and chemical weathering. The feldspars are not resistant to weathering and so they are weathered to form clays which were observed all over the stream channels and alluvial soil. The pegmatite was observed to be trending in NW-SE, this is because of the great tectonic deformation that took place in the area and some part of the Older Granites of the Nigerian Basement Complex during the Pan African orogeny which was studied and dated to be $677 \mathrm{Ma}-518 \mathrm{Ma}$ using $\mathrm{Rb} / \mathrm{Sr}$ and $\mathrm{U} / \mathrm{Pb}$ radioactive dating. Petrographically, the quartz crystals of the rock samples of the study area were observed to be highly cracked and have an anhedral form which proves that the rocks were highly deformed. The great tectonic activities that took place might have led to the exposure of the rocks to the surface of the study area.

The variation in colour of the different granitic rocks is as a consequence of high percentage of some minerals present in the magma during their formation. Porphyritic granite and coarse grained granite (samples 1and 5) are rich in feldspar, biotite and quartz thus have a pinkish dark grey colour, porphyritic granite, coarse and medium grained granites (samples 4, 7, 10, and 14) have a very high percentage of feldspar and biotite, therefore it is pinkish dark in colour, whilst coarse and medium grained granites (samples 2 and 9) are rich in quartz and biotite and have dark gray colouration.

Some minerals are observed to be associated with only a particular rock and some with two or more rock types as observed optically. Limonite is only associated with porphyritic granite. Myrmekite is almost associated with the porphyritic granite, coarse grained granite and medium grained granites (samples 4, 5, 7, 9, 10 and 14) because it forms as a result of intergrowth of quartz in plagioclase which are both present in the rock. The slow cooling of the magma leads to vermicular intergrowth of quartz in albite which forms the myrmekite. Zircon and hornblende are also associated with porphyritic granite and coarse grained granites (samples 2, 4, 5, 7) and coarse grained granite (sample 7) respectively because they were readily present in the crystallizing magma during the time of their formation, so also why sphene is only associated with coarse grained granites and medium grained granite (samples 2, 7, and 10). Sericite is only found in porphyritic granite, coarse grained granite and medium grained granite (samples 2, 4, 10 and 14). Muscovite is only associated with coarse grained granite (sample 5). Iron oxide on the other hand is almost associated with all the samples.

Weathering is essentially biological as animals and roots of trees obviously penetrated the parent rocks breaking them into smaller fragments. Structures such as joints, fractures and faults were observed and some measurements of dip and strike were made.

The granitic rocks in the study area are rich in feldspar; a single crystal of feldspar (phenocryst) was measured to be $18 \mathrm{~cm} \times 12 \mathrm{~cm}$ thick, which can be mined at profit by Glass and Ceramic industries for making products. The feldspars can also be mined for making cement and fertilizers. The granitic rock itself can be quarried for construction purposes such as building houses, roads, bridges etc and can also be used for making decorative stones such as tiles.

\section{Conclusion}

Geological study of the rocks in parts of the study area revealed some granitic rocks with distinctive colour, mineralogical, textural and petrographic properties which have implication on their overall geology. The rocks occurring in Kaltungo inlier are essentially composed of porphyritic granite, coarsed biotite granite and medium grained granite with some basaltic intrusions piercing the overlying Bima sandstone. Presence of joints, fractures and faults indicate that the area has suffered some tectonic activities. Despite their distinction, both 
field and laboratory evidences show that the area is part of the exposed basement complex of Nigeria which outcropped in the study area and the geological map produced summarized the geology of the area.

\section{Acknowledgement}

I (the first author) acknowledged the distinguished Lecturers and the Head of Geology department Dr. A. A. Zarma for their tireless support and encouragement, the effort of the Laboratory Technologists and the non academic staff of the department is also appreciated. I equally wish to thank my able supervisor Prof. Saidu Baba for his time, understanding, constructive criticisms and suggestions. The effort of Malam Modu Usman for preparing the thin slides is also appreciated. I alone remain responsible for any mistake that escapes scrutiny. The financial and moral contributions of my Uncle, Prof. U. I. Ibrahim of the department of Veterinary Medicine of the University is fully acknowledged. The hospitality shown by Prof. Saliba James of History department of the University and his family there in Kaltungo for accommodating me and my colleagues during the course of the fieldwork is acknowledged. The effort of Kaltungo Emirate Council (HRH Engr. Saleh Muhammadu OON Mai Kaltungo, Magajin Gari, District Heads, Auwal, Masoro and Sarkin Zagi among others) and the entire people of Kaltungo and nearby villages for allowing us carry out the field work peacefully; perhaps traversing through their farms and houses harmlessly is also recognized.

\section{References}

[1]. Baba, S. (2009). Planning for Geological Fieldwork in a Semi-arid Zone. Proceedings of Field Mapping Standardization Workshop. Ibadan University Press. pp 65-77

[2]. Benkhelil, J., and Robineau, B. (1983). Fault Rocks of Kaltungo Lineament of North-eastern Nigeria and their Relationship with the Benue Trough Tectonics. Journal of the Geological Society. 143, 567-569

[3]. Carter, J. D., Barber, W., and Tait, E. A., (1963). The Geology of Part of Adamawa, Bauchi and Borno Provinces in North-eastern Nigeria. Geologic Survey Agency of Nigeria, Bulleting No. 30, pp 76-84

[4]. Falconer, J. D. (1911). The Geology and Geography of Northern Nigeria, MacMillan London, 195p

[5]. Islam, M. R., and Baba S. (1988). A Report of Northern Part of Mandara Hills, Nigerian Journal of Borno. Vol. 1 No. 7. pp 99105

[6]. Rowland, E. O. (1953). Rapid Method for Preparation of Thin Rock Sections Mineral. Mag., 30, 254-258 